\title{
Effect of Ovariectomy with and without Replacement Therapy on Calcium Metabolism in Female Albino Rats
}

\author{
Saad Kamal Taha*, Salah El Din Aziz El-Sayed, \\ Merhan Mamdouh Ragy \\ Physiology Depts., Faculties of Medicine, *El-Azhar \& El-Minia \\ Universities
}

\begin{abstract}
Osteoporosis is a chronic, progressive disease of the skeleton characterized by decreased bone mass due to a reduction in both organic and non organic components. Women are more likely to develop the disease, especially postmenopausal women. The aim of the present work was to assess the effect of ovariectomy with or without replacement therapy on calcium metabolism in female albino rats and the possibility of preventing progression of osteoporosis by means of hormonal supplementation and to compare the effects of different supplementations.

The present study was done on 90 adult female albino rats that were divided four weeks after bilateral ovariectomy (OVX) (except the control group) into nine equal groups as follow: Control group (non-ovariectomized), Ovariectomized group, Ovariectomized estrogen treated (30 $\mu \mathrm{g} / \mathrm{kg} /$ day SC, 8 weeks) group, Ovariectomized progesterone treated (10 mg/kg/day SC, 8 weeks) group, Ovariectomized estrogen (25 $\mu \mathrm{g} / \mathrm{kg} /$ day SC, 8 weeks) and progesterone $(10 \mathrm{mg} / \mathrm{kg} /$ day S.C., 8 weeks) treated group, Ovariectomized calcium treated $(70 \mu \mathrm{L} /$ day - calcium gluconate $0.24 \mathrm{gm} / \mathrm{ml}$ - orally, 8 weeks) group, Ovariectomized calcitonin treated (10 IU/kg SC, 8 weeks) group, Ovariectomized calcitonin and calcium treated group, Ovariectomized vitamin D treated $(0.5 \mu \mathrm{g} / \mathrm{kg}$ orally, 8 weeks) group. Blood samples were collected, centrifuged and used for determination of calcium, phosphorous, parathormone and calcitonin serum levels. The left femur of each rat was removed, cleaned, weighted in air and in water and the bone density was determined. Fat-free dry femurs obtained by extracting the femurs for $48 \mathrm{~h}$ in $90 \%$ petroleum ether and dried in a forced-air oven at $90^{\circ} \mathrm{C}$ until constant weight was obtained. The bone ash weight which contains the minerals was obtained after ashing at $600^{\circ} \mathrm{C}$ for $24 \mathrm{~h}$. On the basis of the obtained weights the percentage of organic and non-organic components were calculated.

The results obtained revealed that ovariectomy produced a significant reduction in bone mineral density (BMD), dry weight, ash content, femoral calcium content and organic matrix weight compared to the control group, indicating that there was a decrease in bone mass rather than a decrease in bone minerals. Serum calcium concentration did not show any significant change following OVX, serum calcitonin level decreased after OVX and increased with estrogen supplementation. The combination groups which were supplemented either with (estrogen and progesterone) or with (calcitonin and calcium) -with insignificant differences between them- increased BMD, dry weight, ash content, organic matrix weight and ash
\end{abstract}


calcium content. The percentage changes in BMD were $18 \%$ and $17.3 \%$ in these groups respectively as compared to the ovariectomized group. Calcitonin decreased serum calcium level, increased partially BMD and increased significantly bone dry weight, organic matrix weight, ash content and ash calcium of left femur, compared to OVX group. The calcium supplemented ovariectomized group had insignificant difference with the ovariectomized group in all femur parameters. When it wss compared with the control group, there was a significant reduction in BMD. This finding could be explained that, calcium deposition in bone could be dependent on calcitonin level which was decreased by ovariectomy. So, calcium potentiates the effect of calcitonin on bone mass that ovariectomized calcitonin and calcium treated female group had better effect on bone mass than calcitonin therapy alone. The bone mass was greater by $16.31 \%$ in vitamin D treated ovariectomized group, $15.96 \%$ in both estrogen and calcitonin treated ovariectomized groups and $15.6 \%$ in progesterone treated ovariectomized group when compared to OVX group. There was a significant higher serum phosphorus concentration in ovariectomized group compared to the control group, while other ovariectomized treated groups had serum phosphorus concentrations that were similar to those of the control group. There was an insignificant change in serum parathormone levels in the ovariectomized and the ovariectomized treated groups compared with the control group.

In conclusion, the present study showed that the combination therapy either with estrogen and progesterone or with calcitonin and calcium was found to be the most effective treatment regimen in OVX rats.

\section{INTRODUCTION}

Bone is a dynamic tissue, being formed and resorbed continually under the control of hormonal and physical factors. Remodeling of bone takes place throughout life, with osteoclasts resorbing old bone and osteoblasts creating new bone. These cells continuously renew the skeleton while maintaining its strength and density. Normally, in the adult skeleton, $3 \%$ of cortical bone and $25 \%$ of trabecular bone are remodeled each year. An imbalance between these processes may result in loss of bone $\operatorname{mass}^{(1)}$.

Osteoporosis is characterized by low bone mass and micro architectural deterioration of bone tissue, with a consequent increase in bone fragility and susceptibility to fracture. The major cause of that disease is cessation of ovarian function after menopause. Estrogen deficiency in mammals increases bone turnover and results in a reduction in bone mass due to an imbalance between bone resorption and bone formation. OVX rats have been widely used as an animal model for the study of the prevention and treatment of postmenopausal osteoporosis. There are many observed similarities between ovariectomy-induced bone loss in rats and postmenopausal bone loss in humans ${ }^{(2)}$.

Several pharmacological agents are available for prevention and treatment of osteoporosis, and they can be classified according to their mechanism of action. The two main classes of drugs used to treat osteoporosis are: the antiresorptive 
agents that block bone resorption by inhibiting the activity of osteoclasts and the anabolic agents that stimulate bone formation by acting primarily on osteoblasts and the antiresorptive drugs include estrogens, bisphosphonates and calcitonin. In contrast to drugs that slow bone turnover, anabolic agents directly stimulate bone formation; these drugs include parathyroid hormone, growth hormone, and sodium fluoride ${ }^{(3)}$.

The aim of the present work was to study the effects of ovariectomy on calcium metabolism with or without elementary substitution and to compare the results with those of hormonal replacement therapy. The effects of estrogen and progesterone supplementation will, also, be differentiated.

\section{MATERIALS \& METHODS}

Ninety adult female albino rats, weighing 200-250 g were used in the study. Rats were housed at room temperature with 12:12 hour light/dark cycles. Rats were randomly classified into the following groups:

1. Control group (C); in which the rats were left freely wondering throughout the period of the experiment.

2. Ovariectomized group (OVX); in which rats were subjected to bilateral ovariectomy under ether anesthesia 4 weeks before the beginning of the experiment ${ }^{(4)}$.

3. Ovariectomized estrogen treated group $(\mathrm{OVX}+\mathrm{E})$; in which rats were subcutaneously injected with estradiol benzoate at a dose level of $30 \mu \mathrm{g} / \mathrm{kg}$ body weight/day, for 8 weeks, started 4 weeks after $\mathrm{OVX}^{(\mathbf{5})}$.

4. Ovariectomized progesterone treated group $(\mathrm{OVX}+\mathrm{P})$; in which rats received progesterone at a dose level of $10 \mathrm{mg} / \mathrm{kg}$ body weight/day, subcutaneously daily for 8 weeks, after 4 weeks after $\mathrm{OVX}^{(\mathbf{5})}$.

5. Ovariectomized estrogen and progesterone treated group $(\mathrm{OVX}+\mathrm{E}+\mathrm{P})$; in which rats received estrogen and progesterone at a dose level of $25 \mu \mathrm{g} / \mathrm{kg}$ body weight/day, subcutaneously and $10 \mathrm{mg} / \mathrm{kg}$ body weight/day, subcutaneously respectively, daily for 8 weeks started 4 weeks, after $\mathrm{OVX}^{(\mathbf{5})}$.

6. Ovariectomized calcium treated female group $(\mathrm{OVX}+\mathrm{Ca})$; each rat received calcium at a dose level of $70 \mu \mathrm{L} /$ day -calcium gluconate $0.24 \mathrm{gm} / \mathrm{ml}$-, orally daily for 8 weeks, started after 4 weeks after OVX. This dose was equivalent to the human dose corrected for rats according to Paget and Barnes (1964).

7. Ovariectomized calcitonin treated group (OVX +Cal); each rat received calcitonin hormone at a dose level of $10 \mathrm{IU} / \mathrm{kg}$ body weight/day, subcutaneously daily for 8 weeks, started 4 weeks after $\mathrm{OVX}^{(4)}$.

8. Ovariectomized calcitonin and calcium treated group $($ ovx $+\mathrm{Cal}+\mathrm{Ca})$; in which each rat received the previous doses of calcitonin and calcium together as groups 6 and 7 .

9. Ovariectomized vitamin $\mathrm{D}$ treated group $(\mathrm{OVX}+\mathrm{VitD})$; in which each rat received vitamin $D_{3}$ at a 
dose level of $0.5 \mu \mathrm{g} / \mathrm{Kg}$, orally daily for 8 weeks started after 4 weeks of being subjected to bilateral ovariectomy ${ }^{(7)}$.

\section{METHODS}

1- Ovariectomy: Except the control group all rats were subjected to bilateral ovariectomy under ether anesthesia $^{(8)}$.

2- Bone volume: The Left femur of each rat was removed, cleaned of soft tissue, wrapped in salinesoaked gauze and stored at $-70^{\circ} \mathrm{C}$ until analyzed for bone density and chemical composition. All femurs were first weighed in air (W), then reweighed while suspended in water (WW) at room temperature. The difference between the two weights is the volume of the bone ${ }^{(\mathbf{9})}$.

3- Bone density (Archimedes' principle): It is the standard method for determination of density $\left(\mathrm{g} / \mathrm{cm}^{3}\right)$ of bones from small animals. Density was calculated using the formula: Density $=W / W-W W X$ PWhere, $\mathbf{P}$ is the density of distilled water at a given temperature and $\mathrm{W}$ WW is the difference in weight, which is equivalent to the bone volume $^{(10)}$.

4- Preparation of dried femurs: The left femurs were first dried to constant weight at $100^{\circ} \mathrm{C}$ for $24 \mathrm{~h}$ and weighed again for the determination of dry weight (DW) which includes organic, minerals, and fat as the water content was only evaporated. On the basis of the obtained initial weights of femur; W and DW, the weight of water content in the femurs was calculated using the formula: $\mathrm{W}_{\text {water }}=\mathrm{W}-\mathrm{DW}$, and the percentage of water content $=\mathrm{W}_{\text {water }} \times 100 / \mathrm{W}^{(11)}$.

5- Preparation of Fat-free dry femurs: Fat-free dry femurs were determined by the method of Watkins and Southern (1992) ${ }^{12}$. The left femurs were extracted for $48 \mathrm{~h}$ in $90 \%$ petroleum ether and were dried in a forced-air oven at $90^{\circ} \mathrm{C}$ until constant weight was obtained.

6- Preparation of femurs ash: The bone ash weight (AW) which contains only the minerals was obtained after ashing at $600{ }^{\circ} \mathrm{C}$ for $24 \mathrm{~h}^{\left({ }^{(13)}\right.}$. Mineral content was calculated as the ratio of ash weight to dry weight. The ash was dissolved in $1 \mathrm{~N} \mathrm{HCl}^{(14)}$ to measure the calcium and phosphate concentrations that were determined spectrophotometrically ${ }^{(\mathbf{1 5})}$. On the basis of the obtained weights (W, DW, and AW), the following calculations were made ${ }^{(11)}$.

$\%$ of non organic component $=$ $\left.\mathrm{W}_{\text {non-org. comp. }} \times 100 / \mathrm{W}\right)$

$\%$ of organic components $=\mathrm{W}_{\text {org. }}$. comp. $\times 100 / \mathrm{W}$ )

7- Determination of serum calcium and phosphates: according to the methods described by Fiereck, $(1976)^{16}$ and Tietz , $(1976)^{17}$, respectively.

8- Determination of serum parahormone (PTH) level according to the method described by Kruger et al. (1995) $^{18}$.

9- Determination of serum calcitonin level $^{(19)}$ 


\section{Statistical Evaluation of the \\ experimental data:}

Data were expressed as the mean \pm SE. Statistical significance of difference between groups was evaluated by unpaired two-tailed Student's " $t$ " test. Values of $p<0.05$ were considered statistically significant (20).

\section{RESULTS}

1- Effect of ovariectomy on left femur parameters:

All left femur parameters in the OVX group had significantly lower values than those from the control except, $\%$ of water content which showed a significant higher level in the OVX group compared with the control group with insignificant difference of the ratio between the non organic to the organic component between the two groups. This is illustrated in table (1)

2- Effect of ovariectomy with estrogen supplementation on left femur parameters:

There were insignificant differences in all left femur parameters between the $\mathrm{OVX}+\mathrm{E}$ group and the control group except the BMD which showed a significant lower value in the $\mathrm{OVX}+\mathrm{E}$ group. There were significant higher values in all left femur parameters in the $\mathrm{OVX}+\mathrm{E}$ group compared to the OVX group except $\%$ of water content which showed a significant lower value with insignificant difference in the ratio of non organic to organic component between the two groups. This is shown in table (1).
3- Effect of ovariectomy with progesterone supplementation on left femur parameters:

There were significant lower values of ash weight and BMD in the $\mathrm{OVX}+\mathrm{P}$ group compared to the control group with insignificant difference in the other parameters between the two groups. There were significant higher values in all left femur parameters in the $\mathrm{OVX}+\mathrm{P}$ group compared to the OVX group except $\%$ of water content and the ratio of non organic to organic component which showed significant lower values. This is illustrated in table (1).

4- Effect of ovariectomy with estrogen and progesterone supplementation on left femur parameters:

There were significant higher values in all left femur parameters in the $\mathrm{OVX}+\mathrm{E}+\mathrm{P}$ group compared to the OVX group except $\%$ of water content which showed a significant lower value with insignificant difference in the ratio of non organic to organic component between the two groups. This is illustrated in table (1).

5- Effect of ovariectomy with calcium supplementation on left femur parameters:

There were insignificant differences in all left femur parameters between the $\mathrm{OVX}+\mathrm{Ca}$ group and the OVX group. All femurs of the $\mathrm{OVX}+\mathrm{Ca}$ group had significantly lower values than those from the control except $\%$ of water content which showed a significant higher level in the $\mathrm{OVX}+\mathrm{Ca}$ group compared with the control group with insignificant difference in the ratio of non organic to organic component 
between the two groups. This is shown in table (2).

6- Effect of ovariectomy with calcitonin supplementation on left femur parameters.

There were insignificant differences in all left femur parameters between the $\mathrm{OVX}+\mathrm{Cal}$ group and the control group except the BMD which showed a significant lower value in the $\mathrm{OVX}+\mathrm{Cal}$ group. There were significant higher values in all left femur parameters in $\mathrm{OVX}+\mathrm{Cal}$ group compared to the OVX group except $\%$ of water content which showed a significant lower value and insignificant difference in the ratio of non organic to organic component between the two groups. This is illustrated in table (2).

7- Effect of ovariectomy with calcitonin and calcium supplementation on left femur parameters:

There were significant higher values in all left femur parameters in the $\mathrm{OVX}+\mathrm{Ca}+\mathrm{Cal}$ group compared to the OVX group except $\%$ of water content which showed a significant lower value with insignificant difference in the ratio of non organic to organic component between the two groups. This is illustrated in table (2).

8- Effect of ovariectomy with vitamin D supplementation on left femur parameters:

There were significant higher values in all left femur parameters in OVX+vit D group compared to the OVX group except $\%$ of water content which showed a significant lower value with insignificant difference in the ratio of non organic to organic component between the two groups. This is illustrated in table (3).

9- Changes in femur calcium and phosphorus content in different groups:

There were significant lower levels of femoral calcium content of the OVX, OVX $+\mathrm{Ca}$ and $\mathrm{OVX}+\mathrm{P}$ groups compared to control group. Other ovariectomized treated groups had femoral calcium content levels that were similar to those of the control group. This is shown in table (4).

There was insignificant change in femoral phosphorus content in the ovariectomized and the ovariectomized treated groups compared with control group. This is illustrated in table (4).

10- Effects of treatment of different drug therapies on serum calcium, phosphorus, parathormone and calcitonin in different groups (Table 5):

There was insignificant change in serum calcium levels in OVX and the ovariectomized treated groups compared with the control group except, OVX+Cal group in comparison to all other groups.

There was significant higher serum phosphorus concentration in OVX group compared to control group, while, other ovariectomized treated groups had serum phosphorus concentrations that were similar to those of the control group.

There was insignificant change in serum parathormone levels in OVX and the ovariectomized treated groups compared with control group.

The OVX group and $\mathrm{OVX}+\mathrm{Ca}$ group showed significant lower serum calcitonin level compared with the 
control group. In all supplemented ovariectomized groups, there was a significant higher value in serum calcitonin level compared with the OVX group.

11- Effect of treatment with different drug therapies on BMD:

The ovariectomized group showed the lowest bone density between all groups compared with the control group. Ovariectomy resulted in $15.5 \%$ decrease in BMD of left femurs. The calcium supplemented ovariectomized group had insignificant difference with the ovariectomized group. When it is compared with the control group, there was a significant reduction by $14.37 \%$. The highest increase BMD was observed among the combination groups which supplemented either with (estrogen and progesterone) or with (calcitonin and calcium). The percentage changes were $18 \%$ and $17.3 \%$ respectively, as compared to OVX group. This is illustrated in figure (1).

12- Effect of treatment of different drug therapies on non organic (ash weight) components of the bone:

There were significant lower levels of ash weights of the OVX, $\mathrm{OVX}+\mathrm{Ca}$ and $\mathrm{OVX}+\mathrm{P}$ treated groups compared to the control group. Other ovariectomized treated groups had bone ash levels similar to those of the control group. This is shown in fig. (2).

Table (1): - Effect of ovariectomy, with estrogen, with progesterone and with estrogen and progesterone supplementation on left femur parameters $(\mathrm{M} \pm \mathrm{SE})$.

\begin{tabular}{|l|c|c|c|c|c|}
\hline \multicolumn{1}{|c|}{ Groups $\mathrm{N}=10$} & $\mathrm{C}$ & $\mathrm{OVX}$ & $\mathrm{OVX}+\mathrm{E}$ & OVX+P & OVX+E+P \\
\hline $\begin{array}{l}\text { Parameters } \\
\text { (mg/mm3) density }\end{array}$ & $3.34 \pm 0.02$ & $2.82 \pm 0.01^{*}$ & $3.27 \pm 0.01^{\circ}$ & $3.26 \pm 0.02^{*}{ }^{\circ}$ & $3.33 \pm 0.01^{\circ}$ \\
\hline FFDW (mg) & $401 \pm 1.7$ & $384 \pm 3^{*}$ & $399 \pm 1.1^{\circ}$ & $397 \pm 1.09^{\circ}$ & $401 \pm 1.1^{\circ}$ \\
\hline Ash weight (mg) & $259 \pm 1.4$ & $244 \pm 1.3^{*}$ & $256 \pm 1.9^{\circ}$ & $254 \pm 1.6^{\circ}$ & $259 \pm 1.6^{\circ}$ \\
\hline $\begin{array}{l}\text { Organic matrix } \\
\text { weight (mg) }\end{array}$ & $160 \pm 2.3$ & $148 \pm 2.3^{*}$ & $161 \pm 2.13^{\circ}$ & $162 \pm 1.5^{\circ}$ & $159 \pm 1.5^{\circ}$ \\
\hline $\begin{array}{l}\text { Ratio of non organic } \\
\text { to organic }\end{array}$ & $1.62 \pm 0.03$ & $1.64 \pm 0.02$ & $1.58 \pm 0.03$ & $1.56 \pm 0.02^{\circ}$ & $1.62 \pm 0.02$ \\
\hline $\begin{array}{l}\% \text { of non organic } \\
\text { components }\end{array}$ & $49.5 \pm 0.20$ & $47.9 \pm 0.25^{*}$ & $49.13 \pm 0.35$ & $48.77 \pm 0.29$ & $49.4 \pm 0.24^{\circ}$ \\
\hline $\begin{array}{l}\% \text { of organic } \\
\text { components }\end{array}$ & $30.5 \pm 0.4$ & $29.1 \pm 0.4^{*}$ & $30.90 \pm 0.4^{\circ}$ & $30.85 \pm 0.28^{\circ}$ & $30.30 \pm 0.2^{\circ}$ \\
\hline$\%$ of water content & $19.8 \pm 0.2$ & $22.8 \pm 0.5^{*}$ & $19.9 \pm 0.3^{\circ}$ & $20.11 \pm 0.34^{\circ}$ & $20.15 \pm 0.1^{\circ}$ \\
\hline
\end{tabular}

*: Significant compared with control group ${ }^{\circ}:$ Significant compared with OVX group

$N$ : is the number of rats in each group

C: Control Group

OVX: Ovariectomized group E: Estrogen

P: Progesterone 
Table (2): - Effect of ovariectomy, with calcium, with calcitonin, with calcium and calcitonin supplementation on left femur parameters $(\mathrm{M} \pm \mathrm{SE})$ :

\begin{tabular}{|l|c|c|c|c|c|}
\hline \multicolumn{1}{|c|}{ Groups N=10 } & $\mathrm{C}$ & OVX & OVX+Ca & OVX+Cal & $\begin{array}{c}\text { OVX+Ca+ } \\
\text { Cal }\end{array}$ \\
\hline $\begin{array}{l}\text { Parameters } \\
\text { (mg/mm3) }\end{array}$ & $3.34 \pm 0.02$ & $2.82 \pm 0.01^{*}$ & $2.86 \pm 0.01^{*}$ & $3.27 \pm 0.02^{\circ}$ & $3.31 \pm 0.02^{\circ}$ \\
\hline Dry weight (mg) & $420 \pm 1.5$ & $392 \pm 2.5^{*}$ & $394 \pm 2.4^{*}$ & $414 \pm 3.1^{\circ}$ & $417 \pm 2.6^{\circ}$ \\
\hline FFDW (mg) & $401 \pm 1.7$ & $384 \pm 3^{*}$ & $383 \pm 3.2^{*}$ & $399 \pm 1.8^{\circ}$ & $400 \pm 1.5^{\circ}$ \\
\hline Ash weight (mg) & $259 \pm 1.4$ & $244 \pm 1.3^{*}$ & $245 \pm 1.5^{*}$ & $256 \pm 1.1^{\circ}$ & $258 \pm 1.8^{\circ}$ \\
\hline $\begin{array}{l}\text { Organic matrix weight } \\
\text { (mg) }\end{array}$ & $160 \pm 2.3$ & $148 \pm 2.3^{*}$ & $148 \pm 2.6^{*}$ & $159 \pm 2.3^{\circ}$ & $160 \pm 1.6^{\circ}$ \\
\hline $\begin{array}{l}\text { Ratio of non organic } \\
\text { to organic }\end{array}$ & $1.62 \pm 0.03$ & $1.64 \pm 0.02$ & $1.65 \pm 0.03$ & $1.60 \pm 0.02$ & $1.61 \pm 0.02$ \\
\hline $\begin{array}{l}\% \text { of non organic } \\
\text { components }\end{array}$ & $49.5 \pm 0.20$ & $47.9 \pm 0.25^{*}$ & $47.9 \pm 0.26^{*}$ & $49.9 \pm 0.11^{\circ}$ & $48.9 \pm 0.22^{\circ}$ \\
\hline $\begin{array}{l}\% \text { of organic } \\
\text { components }\end{array}$ & 30.50 .4 & $29.1 \pm 0.4^{*}$ & $28.9 \pm 0.5^{*}$ & $30.4 \pm 0.3^{\circ}$ & $30.34 \pm 0.2^{\circ}$ \\
\hline$\%$ of water content & $19.8 \pm 0.2$ & $22.8 \pm 0.5$ & $23.1 \pm 0.5^{*}$ & $20.2 \pm 0.3^{\circ}$ & $20.4 \pm 0.2^{\circ}$ \\
\hline
\end{tabular}

*: Significant compared with control group $:$ : Significant compared with OVX group

$N$ : is the number of rats in each group

C: Control Group

OVX: Ovariectomized group

E: Estrogen P:Progesterone Ca: Calcium Cal: calcitonin

Table (3):-Effect of ovariectomy with vitamin D supplementation on left femur parameters $(\mathbf{M} \pm \mathbf{S E})$ :

\begin{tabular}{|c|c|c|c|}
\hline $\begin{array}{ll}\text { Parameters } & \text { Groups } \mathrm{N}=10 \\
\end{array}$ & $\mathrm{C}$ & OVX & OVX+vit D \\
\hline Bone density (mg/mm3) & $3.34 \pm 0.02$ & $2.82 \pm 0.01 *$ & $3.28 \pm 0.01 *^{\circ}$ \\
\hline Dry weight $(\mathrm{mg})$ & $420 \pm 1.5$ & $392 \pm 2.5 *$ & $415 \pm 1.8^{\circ}$ \\
\hline FFDW (mg) & $401 \pm 1.7$ & $384 \pm 3 *$ & $399 \pm 1.3^{\circ}$ \\
\hline Ash weight (mg) & $259 \pm 1.4$ & $244 \pm 1.3 *$ & $257 \pm 1.4^{\circ}$ \\
\hline Organic matrix weight $(\mathrm{mg})$ & $160 \pm 2.3$ & $148 \pm 2.3^{*}$ & $158 \pm 1.3^{\circ}$ \\
\hline Ratio of non organic to organic & $1.62 \pm 0.03$ & $1.64 \pm 0.02$ & $1.61 \pm 0.01$ \\
\hline$\%$ of non organic components & $49.5 \pm 0.20$ & $47.9 \pm 0.25^{*}$ & $49 \pm 0.1^{\circ}$ \\
\hline$\%$ of organic components & $30.5 \pm 0.4$ & $29.1 \pm 0.4^{*}$ & $30.3 \pm 0.25^{\circ}$ \\
\hline$\%$ of water content & $19.8 \pm 0.2$ & $22.8 \pm 0.5^{*}$ & $20.4 \pm 0.24^{\circ}$ \\
\hline \multicolumn{4}{|c|}{$\begin{array}{l}\text { *: Significant compared with control group } \\
\text { : Significant compared with ovariectomized group }\end{array}$} \\
\hline $\begin{array}{l}N: \text { is the number of rats in each group } \\
\text { OVX: Ovariectomized group }\end{array}$ & \multicolumn{3}{|c|}{$\begin{array}{l}C: \text { Control Group } \\
\text { vit D: vitamin D }\end{array}$} \\
\hline
\end{tabular}


Table (4): - Changes in femur minerals content in relation to different therapies in normal and ovariectomized rats $(\mathrm{M} \pm \mathrm{SE})$.

\begin{tabular}{|l|c|c|}
\hline Groups N=10 & $\begin{array}{c}\text { Calcium } \\
(\mathrm{mg} / \mathrm{g})\end{array}$ & $\begin{array}{c}\text { Phosphorus } \\
(\mathrm{mg} / \mathrm{g})\end{array}$ \\
\hline Control group & $68.92 \pm 0.42$ & $31.32 \pm 0.41$ \\
\hline Ovariectomized & $65.4 \pm 0.48^{*}$ & $32.35 \pm 0.26$ \\
\hline OVX + E+ P & $68.77 \pm 0.38^{\circ}$ & $31.25 \pm 0.39$ \\
\hline OVX + Ca+Cal & $68.75 \pm 1.07^{\circ}$ & $32.52 \pm 0.46$ \\
\hline OVX+ vit D & $67.97 \pm 0.56^{\circ}$ & $32.20 \pm 0.35$ \\
\hline OVX + calcitonin & $67.92 \pm 0.36^{\circ}$ & $31.45 \pm 0.29$ \\
\hline OVX + Estrogen & $67.80 \pm 0.37^{\circ}$ & $31.87 \pm 0.49$ \\
\hline OVX + progesterone & $65.97 \pm 0.51^{*}$ & $31.55 \pm 0.31$ \\
\hline OVX + calcium & $65.05 \pm 0.8^{*}$ & $32.32 \pm 0.30$ \\
\hline
\end{tabular}

*: Significant compared with control group

: Significant compared with ovariectomized group

E: Estrogen P: Progesterone

Ca: Calcium Cal: calcitonin

Table (5):- Effects of treatment of different drug therapies on biochemical parameters in OVX rats $(\mathrm{M} \pm \mathrm{SE})$ :

\begin{tabular}{|l|c|c|c|c|}
\hline Groups N=10 & $\begin{array}{c}\text { Calcium } \\
(\mathrm{mg} / \mathrm{dl})\end{array}$ & $\begin{array}{c}\text { Phosphorous } \\
(\mathrm{mg} / \mathrm{dl})\end{array}$ & $\begin{array}{c}\text { Parathormone } \\
(\mathrm{Pg} / \mathrm{ml})\end{array}$ & $\begin{array}{c}\text { Calcitonin } \\
(\mathrm{Pg} / \mathrm{ml})\end{array}$ \\
\hline Control group & $10.2 \pm 0.15$ & $7.4 \pm 0.08$ & $2.4 \pm 0.09$ & $20.2 \pm 0.4$ \\
\hline Ovariectomized & $10 \pm 0.10$ & $9.7 \pm 0.14^{*}$ & $2.6 \pm 0.01$ & $16.8 \pm 0.2^{*}$ \\
\hline OVX+E+ P & $10 \pm 0.14$ & $7.3 \pm 0.12^{\circ}$ & $2.5 \pm 0.1$ & $21.2 \pm 0.5^{\circ}$ \\
\hline OVX+ Ca+Cal & $10.1 \pm 0.13$ & $7.4 \pm 0.1^{\circ}$ & $2.2 \pm 0.1$ & $20.4 \pm 0.3^{\circ}$ \\
\hline OVX+ vitamin D & $10 \pm 0.12$ & $7.6 \pm 0.1^{\circ}$ & $2.4 \pm 0.1$ & $19.2 \pm 0.4^{\circ}$ \\
\hline OVX + calcitonin & $9.21 \pm 0.05^{\circ} *$ & $7.7 \pm 0.1^{\circ}$ & $2.4 \pm 0.1$ & $19 \pm 0.3^{\circ}$ \\
\hline OVX + Estrogen & $10 \pm 0.10$ & $7.5 \pm 0.16^{\circ}$ & $2.3 \pm 0.1$ & $21.4 \pm 0.6^{\circ}$ \\
\hline OVX+ progesterone & $9.9 \pm 0.21$ & $7.2 \pm 0.13^{\circ}$ & $2.5 \pm 0.1$ & $20.4 \pm 0.3^{\circ}$ \\
\hline OVX + calcium & $10.4 \pm 0.18$ & $7.7 \pm 0.06^{\circ}$ & $2.3 \pm 0.1$ & $17.7 \pm 0.4^{*}$ \\
\hline
\end{tabular}

*:Significant compared with the control group

$\because$ Significant compared with the ovariectomized group (OVX)

E: Estrogen P: Progesterone Ca: Calcium Cal: calcitonin 


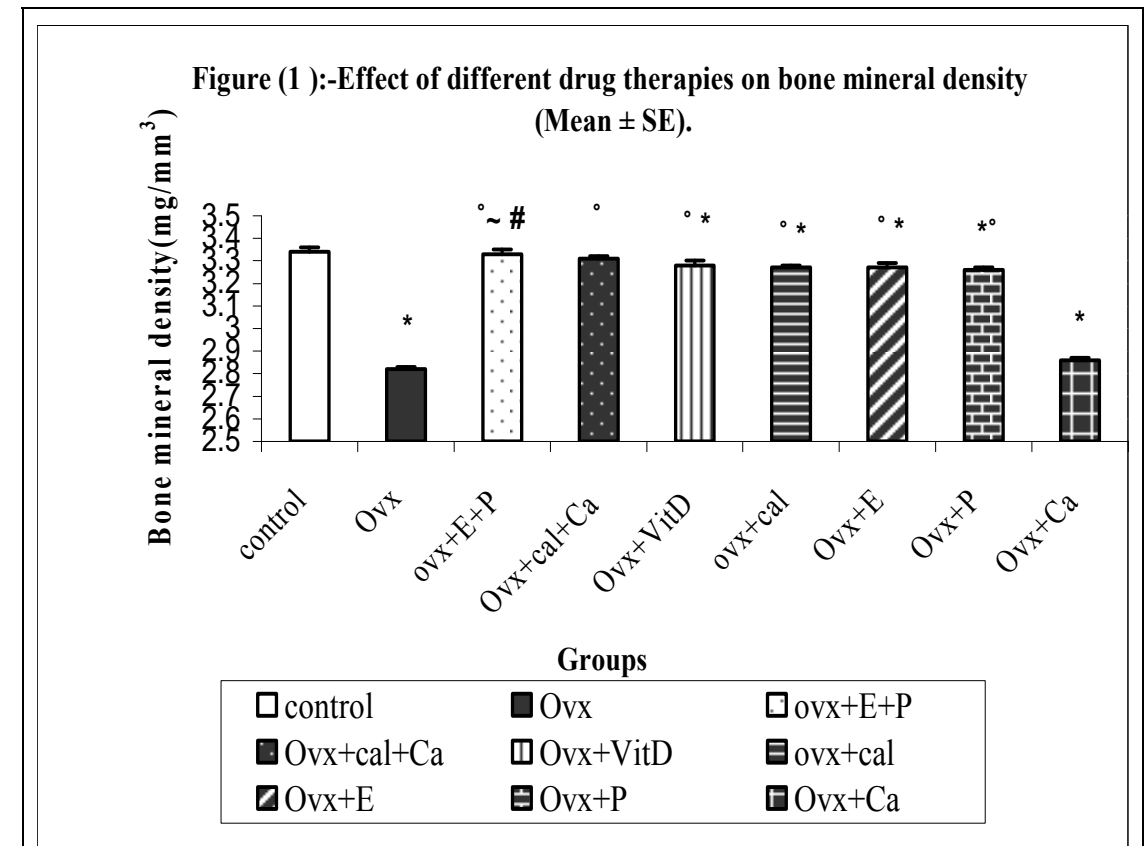

*: Significant compared with control group $\quad$ : Significant compared with OVX group \#: Significant compared with OVX+E group $\quad \sim$ : Significant compared with OVX+E + Proup OVX: ovarictomized E: estrogen P:progesterone Ca:calcium Cal: calcitonin

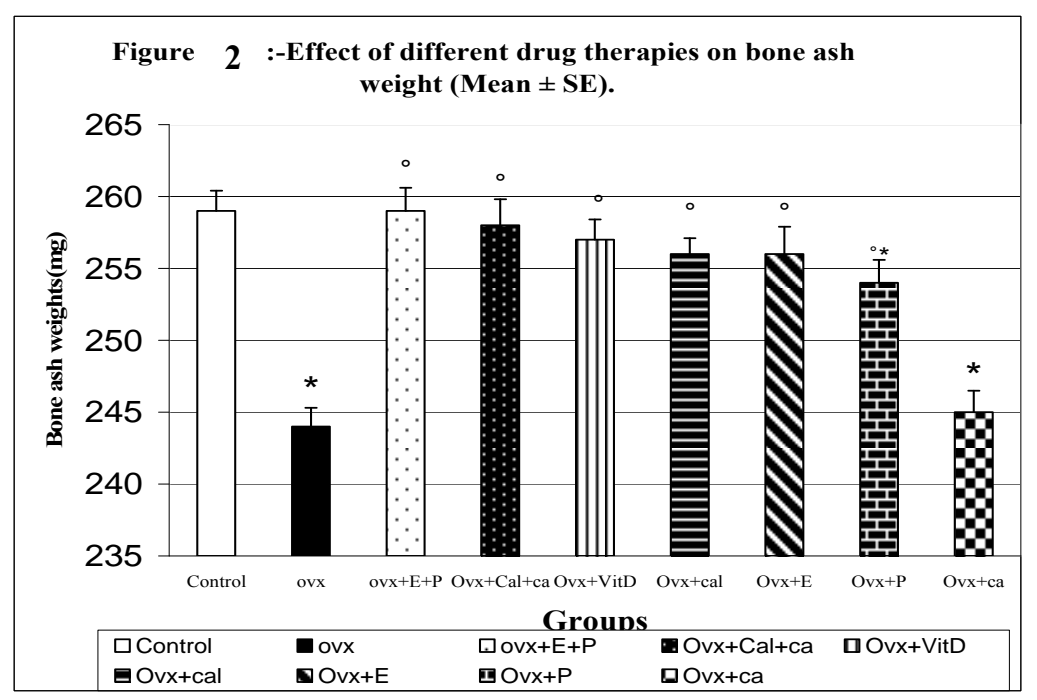

*: Significant compared with control group $\quad$ : Significant compared with OVX group OVX: ovarictomized E: estrogen P: progesterone Ca: calcium Cal: calcitonin 


\section{DISCUSSION}

Osteoporosis is a reduction in the amount of bone tissue per unit volume. Estrogen deficiency after menopause is an important cause of osteoporosis. For this reason, hormone replacement therapy is often recommended for osteoporosis prevention and treatment ${ }^{(21)}$.

The aim of the present work was to study the effect of OVX on calcium metabolism with or without elementary substitution and to compare the results with those of hormonal replacement therapy. The effects of estrogen and progesterone replacement were also differentiated. Therefore, in the present study OVX rats have been used as an animal model for the study of the prevention and treatment of postmenopausal osteoporosis.

The results obtained in the present study demonstrated that OVX induced a significant decrease in BMD and the femoral BMD of OVX rats was $15.5 \%$ lower than that of control group and that finding is matched with that of Kruger et al. ${ }^{22}$ and Hidaka et al. $^{\mathbf{2 3}}$ who concluded that ovariectomy resulted a significant reduction in BMD.

The present study demonstrated that the dry weight, ash content and organic matrix weight of left femurs of OVX group were significantly lower than that of the control group, indicating that there was a decrease in bone mass rather than a decrease in bone minerals. Similar finding was observed by Reddy and Lakshmana $^{24}$. That finding could explain that osteoprosis induced by ovariectomy is characterized by decreased bone mass with preservation of normal ratio of mineral to matrix.

The results obtained in the present study, also, demonstrated that serum calcium concentration did not show any significant change following ovariectomy. Similar finding was observed by Zhang et al. ${ }^{25}$ who reported that serum calcium level in OVX rats was insignificantly changed at 4 weeks, and decreased significantly at 18 weeks following ovariectomy by increased urinary calcium excretion. This could be explained by the fact that homeostatic mechanisms were able to maintain serum calcium level for four weeks despite ovariectomy ${ }^{(26)}$. The homeostatic mechanisms which maintained serum calcium level after ovariectomy may be explained by the finding that estrogen deficiency increases the sensitivity of bone to PTH and other resorption-inducing agents and this further enhances the resorption defect ${ }^{(27)}$.

The obtained data demonstrated that ovariectomy induced a significant increase in serum phosphate concentration. Similar finding was observed by Gopala Krishnan et al. ${ }^{28}$ who, also, reported that serum levels of phosphate were elevated significantly in ovariectomized rats. This could be explained by Dick et al. $^{29}$ who reported that estrogen inhibits selectively sodium phosphate cotransport by direct interaction with estrogen receptors in proximal tubular cells and hence, proximal phosphate reabsorption. 
The present study demonstrated that serum calcitonin level decreased after OVX and increased with estrogen supplementation. Similar findings were observed by Filipović et al. ${ }^{30 \& 31}$ who reported that estrogen deficiency after OVX reduced the synthesis and release of calcitonin, while chronic treatment with estrogen had a positive effect on calcitonin secretory activity in thyroid $\mathrm{C}$ cells of OVX rats.

In the present study, the highest increase in BMD was observed among the combination groups which were supplemented either with estrogen and progesterone or with calcitonin and calcium. This may suggest that the antiresorptive action of estrogen and progesterone could be mediated apart by an increase in calcitonin levels.

The results obtained in the present study demonstrated that estrogen and progesterone together give complete improvement in BMD but either estrogen or progesterone therapy alone give partial improvement. These findings are in agreement with that of Moskowitz ${ }^{32}$, indicating that, estrogen and progesterone in balance enhance each other. This enhancement could be explained by the results of Pei et al. ${ }^{33}$ who evaluated whether the capacity for proliferation and differentiation of progesterone-dependent

osteoprogenitors in the female rat skeleton is related to the level of progesterone receptors and/or the level of circulating estrogen

The results obtained in the present study demonstrated that estrogen increased partially BMD. This finding is in agreement with that of Wang et al. $^{34}$ who found that estrogen increased the bone density of the OVX rat femurs by up-regulating the expression of osteoprotegerin.

The results obtained in the present study demonstrated that progesterone partially increased bone mass. These finding are in agreement withthose of Suliman et al. ${ }^{35}$ who reported that in ovariectomized rat supplemented with progesterone, bone mass was protected by high level of progesterone present. This finding however, was in disagreement with that of Roux et al. ${ }^{36}$ who found that dydrogesterone did not prevent bone loss due to ovariectomy in rats.

The results obtained in the present study demonstrated that plasma parathormone showed insignificant change in the ovariectomized and the ovariectomized treated groups compared with the control group. These results are matched with those of Vincent et al. ${ }^{37}$ who reported that estrogen treatment or withdrawal had no significant effect on either basal or stimulated PTH secretion.

Calcitonin replacement in the present work decreased serum calcium, increased partially BMD and increased significantly bone dry weight, organic matrix weight, ash content and ash calcium of left femurs as compared to OVX group. These findings are in agreement with those of Zaidi et al. ${ }^{38}$ who reported that calcitonin lowers serum calcium concentrations by decreasing bone resorption and increasing urinary calcium excretion and, also, those of Zake et al. ${ }^{39}$ reported who that after treatment of OVX rats with calcitonin, bone density gave partial improvement and bone ash headed 
towards normal ranges in comparison with group of OVX rats without calcitonin supplementation.

Kavuncu et al., ${ }^{4}$ reported that calcitonin treatment resulted in an increase in spinal BMD and the effect of CT on bone structure in vivo appears to be dependent on the rate of bone turnover at the time of treatment. Treatment of OVX rats immediately following the operation with calcitonin for 6 weeks prevented the development of osteoprosis. Calcitonin induced-effect may be explained probably through its binding to osteoclasts receptors ${ }^{(38)}$. This binding leads to loss of the ruffled border, cessation of motility and inhibition of osteoclastic secretion of proteolytic enzymes and the proton pump. Chronic administration of calcitonin reduces the number of osteoclasts $^{(40)}$. It is a potent inhibitor of osteoclastic bone resorption and has been reported to exert analgesic effects, properties which have led to its use as a treatment for postmenopausal osteoporosis $^{(41)}$.

Despite a fall in serum calcium in OVX Calcitonin treated group, there was no effect of ovariectomy on PTH. These data suggest that the decrease in ionized calcium was insufficient to produce a response from the parathyroid gland. In a previous study by Mason and Morris ${ }^{42}$ who studied the effect of hypocalcemia on PTH secretion in ovariectomized rats found that serum levels of PTH were only increased when blood ionized calcium levels fell below $5.2 \mathrm{mg} / \mathrm{dl}$.

The results obtained in the present study demonstrated that calcium supplementation alone did not produce any increase in bone density in ovariectomized rats. This could suggest that calcium deposition in bone could be dependent on calcitonin level which was decreased by ovariectomy. Ku et al., ${ }^{43}$ reported that estrogen deficiency decreases intestinal calcium absorption and the positive effect of calcium does in menopause is more related to building peak bone mass before the onset of menopause and doesn't affect the quantity of bone lost during the initial years of menopause.

In the present study, it was found that calcium potentiated the effect of calcitonin on bone mass that ovariectomized calcitonin and calcium treated female group had better effect on bone mass than calcitonin therapy alone. These findings are in agreement with Nieves et al. ${ }^{44}$ who reported that additional calcium to standard antiresorptive therapy can benefit bone mass.

The results obtained in the present study demonstrated that active vitamin $\mathrm{D}_{3}$ increased bone density in ovariectomized rats. This finding is in agreement with Shibata et al. ${ }^{45}$ who reported that administration of vitamin $\mathrm{D}_{3}$ inhibited tibial and vertebral bone loss because of estrogen deficiency in OVX rats.

The role of vitamin D metabolites in the treatment of osteoporosis is still controversial. Some clinical studies have suggested that therapy of patients with osteoporosis with active vitamin D metabolites increases BMD in the spine and forearm and reduces vertebral fractures ${ }^{(\mathbf{4 6})}$. However, other studies have provided negative results ${ }^{(47)}$. Studies in rats have shown clearly that active vitamin D metabolites can fully prevent estrogen 
deficiency-induced bone loss by suppression of bone resorption $^{(\mathbf{4 8})}$.

The effect of $1,25(\mathrm{OH})_{2} \mathrm{D}_{3}$ on bone is an indirect one, mediated by stimulation of calcium absorption from the intestine with a resultant

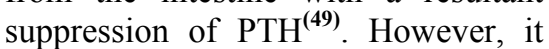
also may have direct antiresorptive effects independent of PTH suppression. Experiments using parathyroidectomized rats infused with human PTH-related peptide 1-34 as a model of hypercalcemia of malignancy have shown that 1,25 $(\mathrm{OH})_{2} \quad \mathrm{D}_{3}$ lowers hypercalcemia and bone resorption in a dose-dependent manner in that model, strongly implying an additional direct antiresorptive action of calcitriol on bone cells ${ }^{(50)}$.

Vitamin $\mathrm{D}_{3}$ acts as a transcriptional regulator of bone matrix proteins, it induces the expression of osteocalcin and suppresses synthesis of type I collagen. Research has shown that vitamin $\mathrm{D}_{3}$ may increase aromatase activity within bone itself, enhancing the local conversion of androgens to estrogens in both men and women. This process does not increase plasma levels of estrogen, but rather limits its production and concentration to bone ${ }^{(51)}$.

In conclusion, the present study provides various therapeutic modalities for management of bone changes following deprivation from sex hormones. It was found that the combination therapeutic regimen as (estrogen with progesterone) is the most effective and protective modality. Calcitonin with calcium is an alternative modality if hormone replacement therapy is contraindicated.

\section{REFERENCES}

1. Simon

L.S.

(2005):

Osteoporosis. Clin. Geriatr. Med., 21(3): 603-29.

2. Phillips A.; Ebbutt A. and France L. (2000): The International Conference on Harmonization guideline "Statistical Principles for Clinical Trials": Issues in applying the guideline in practice. Drug Inf. J., 34(2):337-348.

3. Sambrook P.N. and Cooper C. (2006): Osteoporosis. Lancet 367: 2010-2018.

4. Kavuncu V.; Sahin S.; Baydas G.; Ilhan N. and Ozercan R. (2003): A comparison of estrogen and two different doses of calcitonin in ovariectomized rats. Yonsei Med. J., 44(3): 508-516.

5. Schmidt I. U.; Wakley G. K. and Turner R. T. (2000): Effects of estrogen and progesterone on tibia histomorphometry in growing rats. Calcif., Tissue Int., 67: 47-52.

6. Paget G.E. and Barnes J.M. (1964): Toxicity tests. In" Evaluation Of Drug Activities, Pharmcometrics" Vol. I.st ed. By Laurence, D. R. and Bacharach, A. L. Academic press, London and New York, pp135-144.

7. Iwamoto J.; Seki A.; Takeda T.; Sato Y. and Yeh J.K. (2006): Comparative effects of alendronate and alfacalcidol on cancellous and cortical bone mass and bone mechanical properties 
in ovariectomize rats. Exp. Anim., 55(4): 357-367.

8. Car/ Lac standard procedures (2003): Gonadectomy in rats and mice. UCSF - Animal Care And Use Program, pp 76-84.

9. Zhang Y. and Coon C.N. (1992): Nutrition Institute on Minerals. Chapter 7. Practical Application.. National Feed Ingredient Association, Chicago, IL, pp 64-77.

10. Keenan M.J.; Hegsted M.; Jones K.L.; Delany J.P.; Kime J.C.; Melancon L.E.; Tulley, R.T. and Hong, K.D. (1997): Comparison of bone density measurement techniques: DXA and Archimedes'principle. J. Bone Miner. Res., 12(11):19031907.

11. Brzoska M.M.; Moniuszko J.; Jurczuk M.; Galazyn-S. M. and Rogalska J. (2001): The effect of zinc supply on cadmium-induced changes in the tibia of rats. Food Chem. Toxicol., 39(7):729-737.

12. Watkins K. L. and Southern L. L. (1992): Effect of dietary sodium zeolite A and graded levels of calcium and phosphorous on growth, plasma, and tibia characteristics of chicks. Poult. Sci., 71:1048-1058.

13. Zhang B. and Coon C. N. (1997): The relationship of various tibia bone measurements in hens. Poult. Sci., 76:16981701.

14. Miles P. H.; Wilkinson N. S. and McDowel L. R. (2001): Analysis of Minerals for Animal Nutrition Research. 3rd ed. Dep. Anim. Sci., University of Florida, Gainesville, pp 342-354.
15. Masse P.G.; Rimnac C.M.; Yamauchi M.; Coburn S.P.; Rucker R.B. and Howell, D.S. (1996): Pyridoxine deficiency affects biomechanical properties of chick tibial bone. Bone 18: 567-574.

16. Fiereck E.A. (1976): Normal value. In Fundamentals of Clinical Chemistry. N.W. Tiez, editor, Saunders, Philadelphia, P 1208-1212.

17. Tietz, N.W. (1976): Fundamentals of Clinical Chemistry, W.B. Saunders Co., Philadelphia, p.166-185.

18. Kruger L.; Rosenblum S.; Zaazra J. and Wong J. (1995): Intact PTH is stable in unfrozen EDTA plasma for 48 hours prior to lab Analysis. Clin. Chem., 6: S47-56.

19. Deftos L.J. (1990): Primer on the Metabolic Bone Diseases and Disorders of Mineral Metabolism, (edited by Favus, N.J.), 1st Edition, American Society for Bone and Mineral Research, pp $53-55$.

20. Winer G.J. (1971): Statistical principles. In: Experimental Design, $2^{\text {nd }}$, McGraw Hill.

21. Bouxsein M.L. (2003): Mechanisms of osteoporosis therapy: A bone strength perspective. Clinical Cornerstone (2): S13-S21.

22. Kruger M.C.; Poulsen R.C.; Schollum L.; Haggart N.; Ram S. and Palmano K. (2006): Comparison between acidic and basic protein fractions from whey or milk for reduction of bone loss in the ovariectomised rat. I. Dairy J., 16: 1149-1156. 
23. Hidaka S.; Okamoto Y.; Nakatsuma A.; Hashimoto K.; Ohnishi S.T. and Yamaguchi M. (2006): Royal jelly prevents osteoporosis in rats: beneficial effects in ovariectomy model and in bone tissue culture model. Evid. Based Complement Alternat. Med., (3):339-348.

24. Reddy P.N. and Lakshmana M. (2005): Assessment of experimental osteoporosis using CT-scanning, quantitative X-ray analysis and impact test in calcium deficient ovariectomized rats. J. Pharmacol. Tox. Methods 52(3): 350-355.

25. Zhang Y.; Lai, W.P.; Leung P.C.; Wu C.F. and Wong M.S. (2007): Short- to mid-term effects of ovariectomy on bone turnover, bone mass and bone strength in rats. Biol. Pharm. Bull., 30(5): 898-903

26. Li X.X.; Hara I. and Matsumiya T. (2002): Effects of osthole on postmenopausal osteoporosis using ovariectomized rats; comparison to the effects of estradiol. Biol. Pharm. Bull., 25(6): 738-742.

27. Shen V.; Birchman R.; Wu D.D. and Lindsay R. (2000): Skeletal effects of parathyroid hormone infusion in ovariectomized rats with or without estrogen repletion. Bone Miner. Res., 15:740-746.

28. Gopala K. V.; Arunakaran J.; Govindarajulu P., and Sinivasn N. (2003): Effects of estradiol and progesterone on vertebral collagen, glycosaminoglycans and phosphatases in ovariectomized adult rats. Horm. Metab. Res., 35(3):137-144.

29. Dick I. M.; Devine A.; Beilby J. and Prince R. L. (2005): Effects of endogenous estrogen on renal calcium and phosphate handling in elderly women. Am. J. Physiol. Endocrinol. Metab., 288: E430E435.

30. Filipović B.; Šošić J. B.; Manojlović S. M.; Nestorović N.; Milošević V. and Sekulić $M$. (2002): The effect of ovariectomy on thyroid $\mathrm{C}$ cells of adult rats. Yugoslav Medical Biochemistry 21: 345-350.

31. Filipović $\quad$ B.; Šošić J. B.; Nestorović N.; Stojanoski N.; Kostić V.; Milošević, V. and Sekulić M. (2003): The thyroid C cells of ovariectomized rats treated with estradiol. Histochemistry and Cell Biology 120: 245-250.

32. Moskowitz D. (2006): A comprehensive review of the safety and efficacy of bioidentical hormones for the management of menopause and related health risks. Altern. Med. Rev., 11(3): 208-223.

33. Pei W.; Bellows C.G.; Jia Y. and Heersche J.N. (2006): Effect of age on progesterone receptor expression, and osteoprogenitor proliferation and differentiation in female rat vertebral cell populations. J. Endocrinol., 190(2): 261-270.

34. Wang Q.; Wang K.Z.; Dang X.Q.; Shi Z. B.; Pei X.W.; Bai C.Y. and Jia X.W. (2006): Effect of estrogen on osteoprotegerin, osteoclast differentiation factor and 
macrophage colony stimulating factor mRNA expressions in ovariectomized rat bone tissue.Nan. Fang. Yi. Ke. Da. Xue. Xue. Bao., 26(4):532-534.

35. Suliman I.A.; El-Bakri N. K.; Adem A.; Mustafa A. and Lindgren J. U. (2001): The effect of ovariectomy and ovarian steroid treatment on growth hormone and insulin-like growth factor-I levels in the rat femur. Orthop. Res., 19(6):1008-1012.

36. Roux C.; Kolta, S.; Chappard C.; Morieux C.; Dougados M. and De Vernejoul, M.C. (1996): Bone effects of dydrogesterone in ovariectomized rats: a biologic, histomorphometric, and densitometric study. Bone 19(5):463-468.

37. Vincent A.; Riggs B.L.; Atkinson E.J.; Oberg A.L. and Khosla, S. (2003): Effect of estrogen replacement therapy on parathyroid hormone secretion in elderly postmenopausal women. Menopause 10: 165-171.

38. Zaidi A; Inzerillo A.M. and Troen B. (2002): Molecular and clinical pharmacology of calcitonin. In: Principle of bone biology (Eds.JP Bilezikian, L. Raisz, G Rodan), PP.1423-1444, Academic Press, San Diego.

39. Zak J.; Kapitola J. and Wallischova J. (2003): Effect of calcitonin on regional blood flow in bones, serum levels of IGF-I and osteocalcin, density and weight of bone ash in oophorectomized rats. Sb. Lek., 104(3): 285-292.

40. Becker, K.L.; Müller, B.; Nylén, E.S.; Cohen, R.; White,
J.C. and Snider, R.H. (2002):

Calcitonin gene family of peptides. Structure, molecular biology, and effects. In: Principles of Bone Biology (2nd ed.), edited by Bilezikian JS, Raisz LG, and Rodan GA.. San Diego, CA: Academic, p. 629639.41.

41. Gennari, C. (2002): Analgesic effect of calcitonin in osteoporosis. Bone 30:67S-70S.

42. Mason, R.A. and Morris, H.A. (1995): Stimulation of PTH secretion in response to hypocalcemia differs with oophorectomy in rats.Bone 16 : $216 \mathrm{~S}-227$.

43. Ku S.K.; LeeH.S. and Lee J.H. (2004): Changes of gastrointestinal argyrophil endocrine cells in the osteoporotic SD rats induced by ovariectomy. J. Vet. Sci., 5(3): 183-188.

44. Nieves J.W.; Komar L.; Cosman, F. and Lindsay $R$. (1998): Calcium potentiates the effect of estrogen and calcitonin on bone mass: review and analysis. Am. J. Clin. Nutr., 67: 18-24.

45. Shibata T.; Shira-I., A.; Sato T.; Masuda A.; Hishiya A.; Ishikura N.; Higashi S.; Uchida Y.; Saito M.O.; Ito M.; Ogata E.; Watanabe $K$. and Ikeda $K$. (2002): Vitamin D hormone inhibits osteoclastogenesis in vivo by decreasing the pool of osteoclast precursors in bone marrow. J. Bone Miner. Res., (4):622-629.

46. Gallagher J.C.; Fowler S.E.; Detter J.R. and Sherman S.S. 
(2001): Combination treatment with estrogen and calcitriol in the prevention of age related bone loss. J. Clin. Endocrinol. Metab., 86: 28-36.

47. Ott S. M. and Chesnut C.H. (1989): Calcitriol treatment is not effective in postmenopausal osteoporosis. Ann. Intern. Med., 110: 72-74.

48. Weber K.; Goldberg, M.; Stangassinger $M$. and Erben R.G. (2001): $1 \alpha$-hydroxyvitamin D2 is less toxic but not bone selective relative to $1 \alpha$ hydroxyvitain D3 in ovariectomized rats. Bone Miner. Res., 16: 639-651.

49. Lau K-H.W. and Baylink D.J. (1999): Vitamin D therapy of osteoporosis: Plain vitamin D therapy versus active vitamin D analog (D-hormone) therapy. Calcif. Tissue Int., 65: 295-306.

50. Endo K.; Katsumata K.; Hirata M.; Masaki T.; Kmura T.; Ikeda K. and Ogata E. (2000): 1,25-dihydroxyvitamin D3 as well as its analogue OCT lower blood calcium through inhibition of bone resorption in hypercalcemic rats with continuous parathyroid hormonerelated peptide infusion. J. Bone Miner. Res., 15:175-181.

51. Yanase T.; Suzuki S.; Goto K.; Nomura M.; Okabe T.; Takayanagi $R$. and Nawata, $H$. (2003): Aromatase in bone: roles of Vitamin D3 and androgens. J. Steroid Biochem. Mol. Biol., 86(3-5): 393-397. 


\section{تأثثير أستتصال المبيضين مع العلاج التعويضي و بدونه علي التمثيل الغذائي} للكالسيوم في أناث الفئران البيضاء

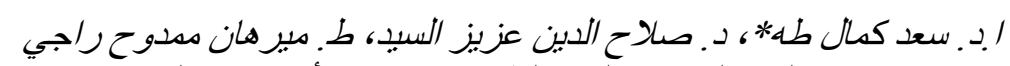

$$
\begin{aligned}
& \text { قسمي الفسيولوجي، كليتي الطب، جامعتي الأزهر * و المنيا }
\end{aligned}
$$

هشاشة العظام تعبير يطلق على نقص غير طبيعي واضتح في كثافة العظام (أي كميـة العظام

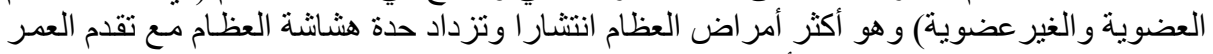

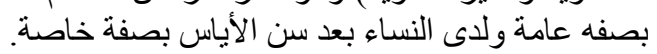

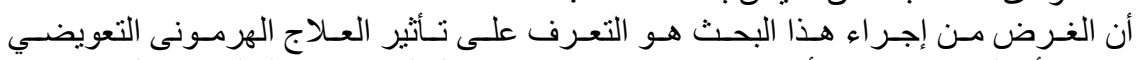

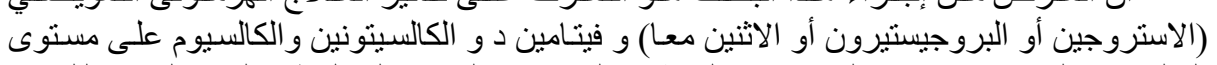

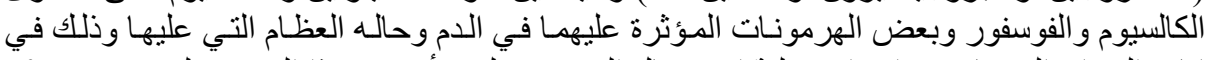

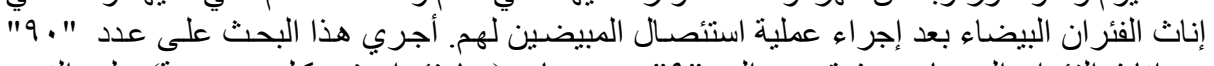

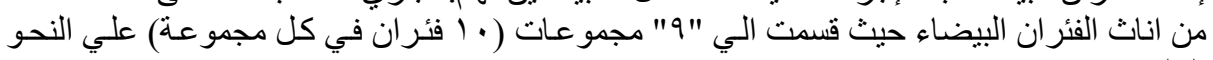
التالي :-

المجموعة الأولى : المجمو عة الضابطة لم تخضع لأستئصال المبيضين أو أب علاج تعويضي.

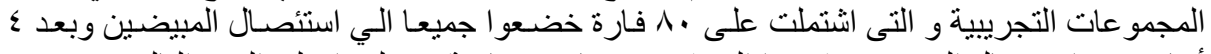

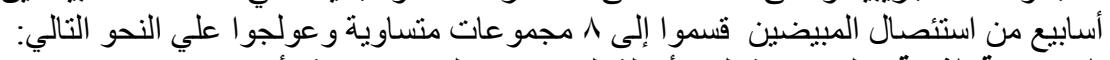

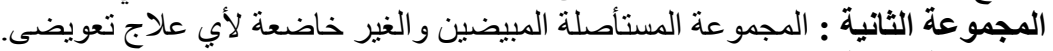

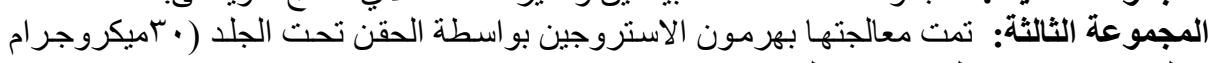

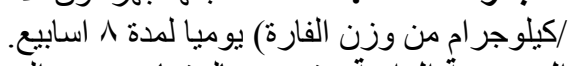

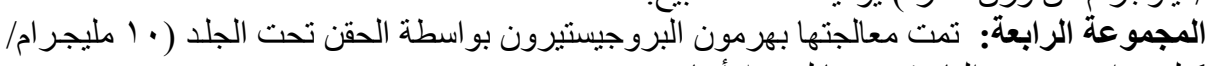

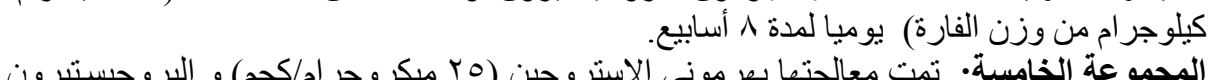

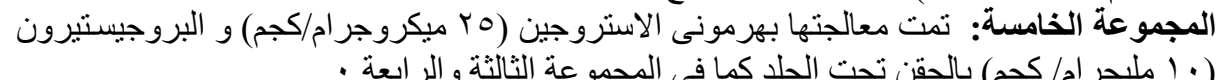

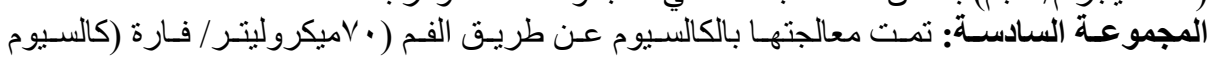

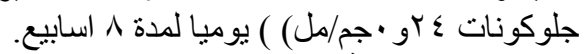

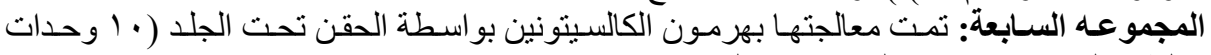
دولية/ كيلوجر ام من وزن الفيعة الفارة) يوميا لمدة 1 اسابيع.

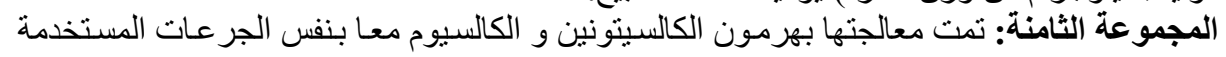

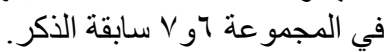

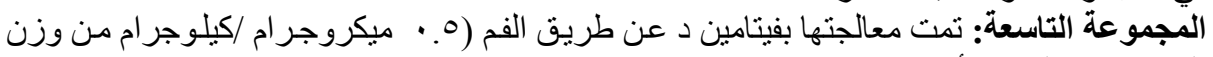

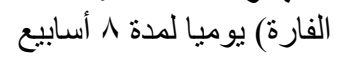

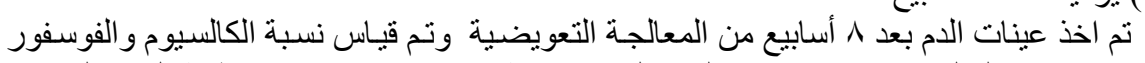

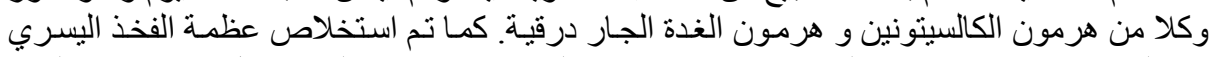

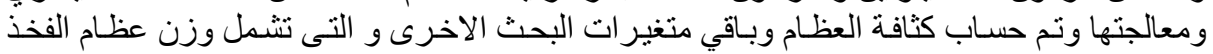

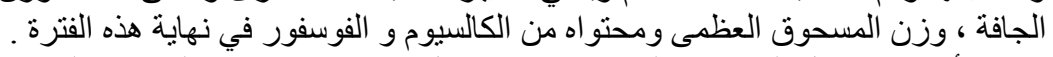

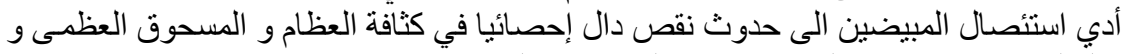

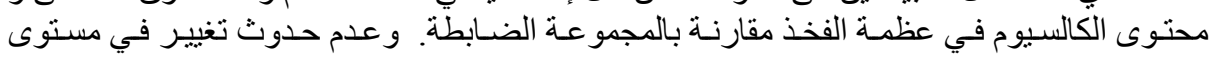


الكالسيوم في الدم في المجموعـة المستأصلة المبيضين مـع حدوث نقص دال إحصـائيا في مستوى الكالسيتونين الذي تحسن بعد المعالجة بالاستروجين.

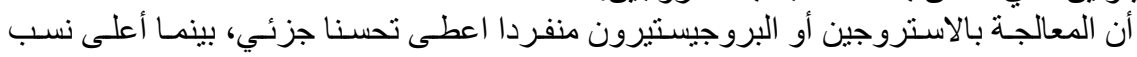

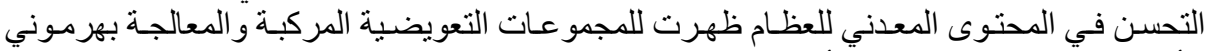

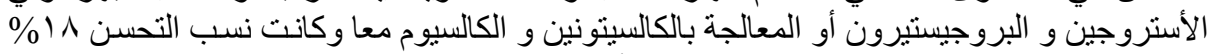

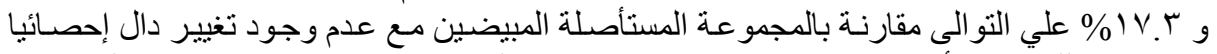

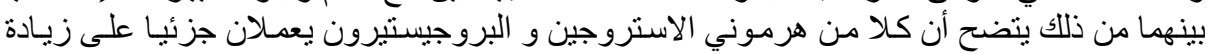

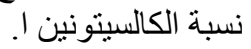

أن الكالسيتونين قد أدي الي نقص في مستوى الكالسيوم في الدم مـع الزيادة الجزئينية في الكثافة الكية

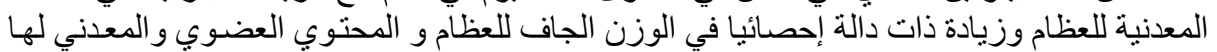

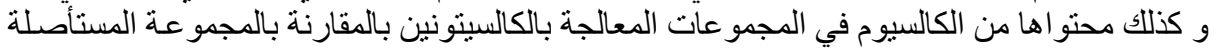

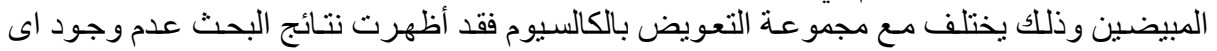

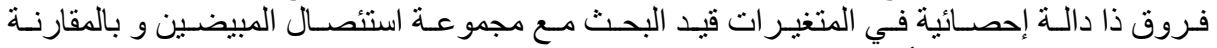

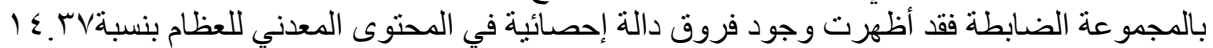

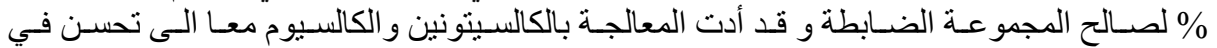
المتغيرات قيد البحث عن استخدام كلا منهما منفردا.

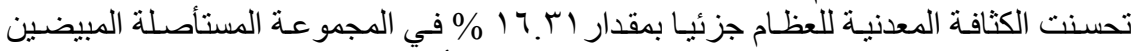

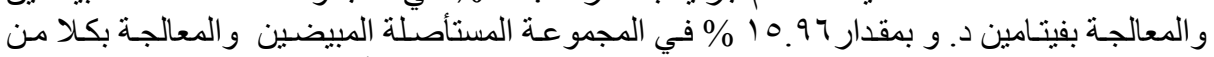

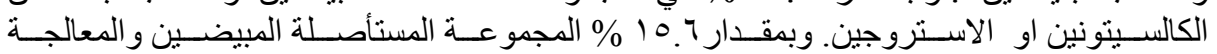

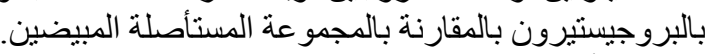

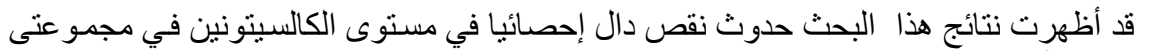

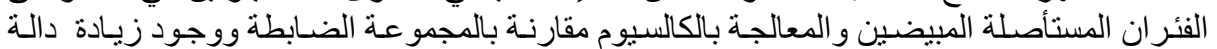

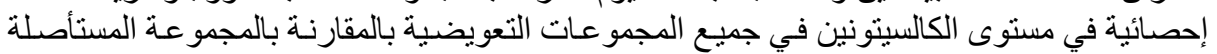

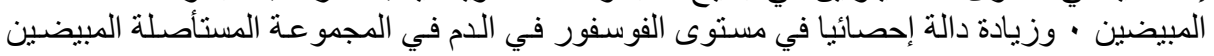

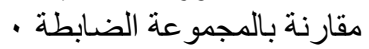

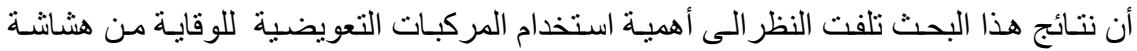

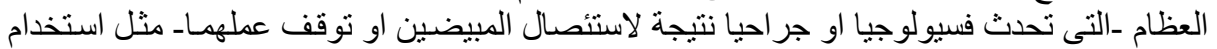

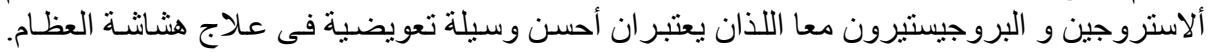

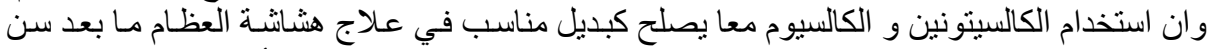

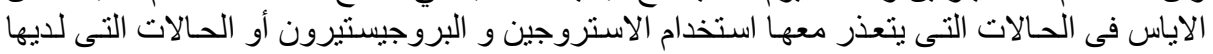
موانع طبية تحول دون استخدامه. 